\title{
Family Support Increases Self-Esteem in Rehabilitation Stroke Patients
}

\author{
Ferishandy Bagaskara ${ }^{1}$, Nina Indriyawati ${ }^{2}$, Suharto ${ }^{2}$ \\ ${ }^{1}$ Program Studi Sarjana Terapan Keperawatan Semarang Poltekkes Kemenkes Semarang \\ ${ }^{2}$ Jurusan Keperawatan Semarang Poltekkes Kemenkes Semarang \\ Corresponding author: ferishandy@gmail.com
}

\begin{abstract}
Background: the number of hemorhagic and non-hemorhagic stroke increase significantly year by year and the number of rehabilitation stage stroke patient that has the problem of family support is still high.

Purpose: this study aims to determine the corellation between the level of family support and the level of self-esteem in stroke patients in the rehabilitation stage.

Methods: the type of research design that researcher used is a correlation test design. The approaching methods that used by the researcher is a cross-sectional study. The researcher uses purposive sampling based on the criteria that researcher made. To obtain the data researcher uses 2 questionaire, that is Family Support Questionaire and RSES (Rosenberg Self-Esteem Scale)

Results: the result of this research is the value of Sig. (2-tailed) Spearman's rank test of family support with the level of self-esteem of stroke patients in the rehabilitation stage is 0.000 or $p<0.05$. Next is the value of Sig. (2-tailed) Spearman rank test of emotional support and appreciation with the self-esteem level of stroke patients in the rehabilitation stage is 0.000 or $p<0.05$, instrumental support with self-esteem is 0.000 or $p<0.05$, and informational support with self-esteem level. esteem is 0.01 or $p<0.05$. Conclusion: there is a corellation between family support both in general and in the aspects such as emotional, appreciation, instrumental, and informational aspects with the level of self-esteem in stroke patients in the rehabilitation stage.
\end{abstract}

Keywords:

Stroke; family support; Self-Esteem; rehabilitation.

\section{LATAR BELAKANG}

Stroke adalah penyakit serebrovaskular pada sistem sensorik pusat (SSP) yang disebabkan oleh gangguan persediaan darah ke otak. Tidak hanya itu, stroke juga dianggap sebagai masalah serebrovaskular yang sering ditemukan di Amerika Serikat, dan merupakan salah satu penyebab utama kematian keempat yang disebabkan oleh penyakit serebrovaskular. (Hinkle \& Cheever, 2017). Stroke dengan gejala klinis juga dapat menimbulkan gangguan otak dalam waktu 24 jam jika tidak ditangani dan dapat menyebabkan kematian tanpa alasan yang jelas. (World Health Organization [WHO], 2016). 
Menurut data yang didapat dari WHO (2014), seluruh dunia pada tiap tahunnya terdapat sejumlah 15 juta kasus stroke, dengan 5 juta dari keseluruhan angka tersebut berujung pada kasus kematian. Selanjutnya, menurut data yang didapat dari Riset Kesehatan Dasar (Riskesdas) antara tahun 2013 hingga 2018 telah terjadi fluktuasi angka terjadinya penyakit stroke. Sementara itu, Provinsi Jawa Tengah sendiri berada pada peringkat sebelas dari total seluruh angka kejadian stroke di seluruh provinsi seIndonesia. Data yang didapat dari Dinas Kesehatan Kabupaten Semarang juga menunjukkan terdapat peningkatan angka kejadian penyakit vaskular sejak periode 2015 - 2018. Selanjutnya, Data dari studi pendahuluan di Rumah sakit dr. Gondo Suwarno Ungaran sejak Januari 2020 - Oktober 2020 ada total 279 pasien stroke. Terdapat sebanyak 54 pasien dengan diagnosa stroke hemoragik dan 225 pasien dengan diagnosa stroke iskemik yang tersebar pada ruang rawat inap dan rawat jalan.

Dari beberapa jenis masalah sering dijumpai pada pasien stroke adalah hemiparesis. Hemiparesis pada umumnya disebut sebagai kelemahan pada salah satu sisi bagian tubuh yang diakibatkan adanya cedera di bagian motorik otak (Hinkle \& Cheever, 2017). Akibat dari penyakit stroke akan menimbulkan kelemahan bagian tubuh bagian ektstremitas yang kedepannya akan mengganggu status fungsional tubuh dan menyebabkan menurunnya tingkat self esteem. Hal tersebut telah dibuktikan melalui penelitian oleh Rahmawati (2019) dimana terdapat responden dengan status fungsional dengan kategori berat memiliki harga diri rendah sebanyak 7 responden $(21,9 \%)$, dengan hasil uji spearman rank diperoleh nilai $\mathrm{p}=-0,054$ atau $\mathrm{p}<0,05$ yang berarti status fungsional akan berpengaruh pada tingkat self esteem.

Self-esteem atau harga diri pada umumnya juga disebut sebagai sebuah proses penilaian oleh individu terhadap kondisi dirinya baik secara positif ataupun negatif. Suatu individu yang tingkat self-esteemnya lebih tinggi akan cenderung memiliki penuh keyakinan, berkompetensi lebih serta mampu menangani masalah - masalah dari kehidupan yang sedang dihadapi (Husnaniyah, 2017).

Tingkat self-esteem yang lebih tinggi pada individu serta hubungan sosial yang kuat pada individu akan bermanfaat dalam mendukung aspek kesehatan bagi penderita untuk merasa lebih baik. Penyakit kronis seperti halnya stroke seringkali dapat mempengaruhi kemampuan penderita untuk memberikan sebuah dukungan yang kemudian dapat mempengaruhi tingkat self-esteem penderita dan peran yang penderita rasakan dalam keluarga (Potter \& Perry, 2016). Sebaliknya, Penderita dengan tingkat self-esteem yang rendah dapat menunjukkan gejala - gejala depresi seperti halnya merasa kehilangan energi, nafsu makan yang menurun, merasa cemas, kehilangan tingkat konsentrasi, dan lain lainnya (Chung et al., 2016).

Pasien stroke yang sudah lama di rawat umumnya akan stabil dan berada pada fase rehabilitasi. Dalam penelitian dari Maulani (2017) didapatkan hasil bahwa masih terdapat $49 \%$ pasien stroke yang menjalani rehabilitasi dengan dukungan dari keluarga yang kurang. Peran serta dukungan keluarga saat tahap rehabilitasi sangat diperlukan. Karena dengan dukungan keluarga yang baik akan mempercepat proses pemulihan dan kedepannya penderita akan merasa semakin mandiri serta percaya diri (Maulani et al., 2017). Hal tersebut telah didukung oleh penelitian Maulani dimana terdapat responden dengan dukungan keluarga baik dan upaya rehabilitasi yang baik sebanyak 33 orang 
(75\%), dengan uji statistic bivariat nilai p-value $=0,037$ maka dapat disimpulkan bahwa ada hubungan yang bermakna antara dukungan keluarga dengan upaya rehabilitasi.

Dengan peningkatan tingkat kemandirian maka self-esteem pada pasien semakin meningkat. Selain hal tersebut, alasan penderita dengan self - esteem rendah membutuhkan dukungan dari keluarga yaitu karena dukungan dari keluarga memiliki peran dalam meningkatkan status fungsional fisik penderita, dan juga status emosional pasien stroke. (Kosasih et al., 2020). Diperlukan dukungan secara emosional, penghargaan, instrumental, informasional bagi pasien stroke agar terjadi peningkatan self esteem (Zai et al., 2019).

\section{TUJUAN}

Penelitian bertujuan untuk dapat mengetahui hubungan tingkat dukungan keluarga dengan tingkat self-esteem pada pasien stroke tahap rehabilitasi.

\section{METODE}

Jenis desain penelitian yang digunakan adalah desain uji korelasi (hubungan) sedangkan jenis pendekatan yang peneliti gunakan adalah studi cross sectional. Sampel yang peneliti gunakan berjumlah 32 orang resnponden pasien stroke tahap rehabilitasi di Rumah Sakit dr Gondo Suwarno Ungaran dan dihitung menggunakan rumus Korelasi Dahlan. Dalam memilih sampel, peneliti menggunakan Purposive Sampling atau dengan kata lain peneliti memilih sampel menggunakan kriteria kriteria yang telah peneliti tentukan sesuai dengan arah penelitian baik kriteria inklusi maupun kriteria eksklusi. Dalam pengambilan data, peneliti menggunakan instrumen dukungan dukungan keluarga dan RSES (Rosenberg Self Esteem Scale).

Setelah data didapatkan, peneliti akan melakukan analisis data dengan bantuan IBM SPSS 26 di perangkat Komputer. Peneliti akan melakukan uji normalitas dengan Shapiro-Wilk dan melakukan analisis bivariat menggunakan uji korelasi Rank Spearman dikarenakan data berdistribusi tidak normal. Dalam menentukan keputusan dari sebuah data disebut berhubungan atau tidak tidaknya dilihat dari nilai signifikansinya. Apabila nilai signifikansinya kurang dari 0,05 maka kedua variabel disebut berkorelasi, namun apabila nilai signifikansinya lebih dari 0,05 maka kedua variabel disebut tidak berkorelasi (Artaya, 2019)

\section{HASIL}

Table 1 tersebut secara holistik peneliti mendapatkan hasil terdapat 13 orang $(40,6 \%)$ responden dengan dukungan keluarga baik dan cukup, serta 6 orang $(18,8 \%)$ responden dengan dukungan keluarga kurang. Selanjutnya, nilai mean dari dukungan keluarga adalah 28,09 yang berarti cukup disertai nilai standar deviasi 6,31. 
Tabel 1. Distribusi tingkat dukungan keluarga responden penelitian di Rumah Sakit dr. Gondo Suwarno Ungaran $(n=32)$

\begin{tabular}{lcc}
\hline Dukungan keluarga & Frekuensi & Persentasi \\
\hline Baik & 13 & 40.6 \\
Cukup & 13 & 40.6 \\
Kurang & 6 & 18.8 \\
Mean $=28.09$, Range $=18-40$, Standar Deviasi $=6.31$, Skewness $=0.086$, Kurtosis \\
$=-.877$
\end{tabular}

.Tabel 2. Distribusi tingkat dukungan keluarga responden menurut domain $(n=32)$

\begin{tabular}{|c|c|c|c|}
\hline Dukungan keluarga & Tingkat & Frekuensi & Persentasi \\
\hline Dukungan & Baik & 13 & $40.6 \%$ \\
\hline emosional dan & Cukup & 14 & $43.8 \%$ \\
\hline penghargaan & Kurang & 5 & $15.6 \%$ \\
\hline \multicolumn{4}{|c|}{ Mean $=8.84$, Standar Deviasi $=2.065$} \\
\hline Dukungan & Baik & 12 & $37.5 \%$ \\
\hline \multirow[t]{2}{*}{ instrumental } & Cukup & 17 & $53.1 \%$ \\
\hline & Kurang & 3 & $9.4 \%$ \\
\hline \multicolumn{4}{|c|}{ Mean $=12.16$, Standar Deviasi $=2.592$} \\
\hline Dukungan & Baik & 5 & $15.6 \%$ \\
\hline \multirow[t]{2}{*}{ informasional } & Cukup & 13 & $40.6 \%$ \\
\hline & Kurang & 14 & $43.8 \%$ \\
\hline Mean $=7.09$, Standa & Deviasi $=2$ & & \\
\hline
\end{tabular}

Berdasarkan domainnya, responden lebih banyak memiliki tingkat dukungan emosional dan penghargaan kategori cukup yakni sebanyak 14 orang $(43,8 \%)$ dengan rata rata skor 8.84 dan nilai standar deviasi 2,065. Selanjutnya, responden lebih banyak memiliki dukungan instrumental kategori cukup, yaitu sebanyak 17 orang $(53,1 \%)$ dengan nilai rata rata skor 12.16 dengan nilai standar deviasi 2,592. Dan yang terakhir, responden lebih banyak dukungan informasional kategori kurang, yaitu sebanyak 14 orang $(43,8 \%)$ dengan nilai rata rata skornya adalah 7.09 dan nilai standar deviasinya 2,220.

Tabel 3. Distribusi tingkat self-esteem responden penelitian di Rumah Sakit dr. Gondo Suwarno Ungaran $(n=32)$

\begin{tabular}{crr}
\hline Self-esteem & Frekuensi & \multicolumn{2}{c}{ Persentasi } \\
\hline Tinggi & 16 & 50.0 \\
Sedang & 12 & 37.5 \\
Rendah & 4 & 12.5 \\
Mean $=27.28$, Range $=18-37, S D=5.810$ & & \\
\hline
\end{tabular}


Berdasarkan tabel 3 mendapatkan hasil terdapat 16 orang (50\%) responden dengan self - esteem tinggi, 12 orang $(37,5 \%)$ responden dengan self esteem sedang, serta 4 orang $(12,5 \%)$ responden dengan self-esteem rendah. Selanjutnya nilai mean dari tingkat dukungan keluarga adalah 27,28 yang berarti sedang dengan nilai standar deviasinya 5,810 .

Tabel 4. Hasil Uji Rank Spearman tingkat dukungan keluarga dengan tingkat self esteem $(n=32)$

\begin{tabular}{lcc}
\hline & Koefisien Korelasi & Sig. (2- tailed) \\
\hline Dukungan & & \\
Keluarga & $.658^{* *}$ & 0.000 \\
\cline { 1 - 1 } Self-Esteem & & \\
\hline
\end{tabular}

Dari tabel 4 diketahui nilai Sig. (2-tailed) adalah 0.000 atau $\mathrm{p}<0.05$ serta nilai koefisien korelasinya 0,658. Maka kesimpulannya secara holistik terdapat hubungan yang signifikan dan kuat antara variabel tingkat dukungan keluarga dengan variabel tingkat self-esteem pada pasien stroke tahap rehabilitasi di Rumah Sakit dr. Gondo Suwarno Ungaran.

Tabel 5. Hasil Uji Rank Spearman tingkat dukungan emosional dan penghargaan dengan tingkat self esteem $(n=32)$

\begin{tabular}{lcc} 
& Koefisien Korelasi & Sig. (2- tailed) \\
\hline Dukungan & & \\
Emosional & & 0.000 \\
dan & $.628^{* *}$ & \\
Penghargaan & & \\
Self-Esteem & & \\
\hline
\end{tabular}

Dari tabel diatas, diketahui nilai Sig. (2-tailed) adalah 0.000 atau $\mathrm{p}<0.05$ serta nilai koefisien korelasinya 0,628. Maka kesimpulannya secara terdapat hubungan yang signifikan dan kuat antara variabel dukungan emosional dan penghargaan dengan variabel tingkat self-esteem pada pasien stroke tahap rehabilitasi di Rumah Sakit dr. Gondo Suwarno Ungaran.

Tabel 6. Hasil Uji Rank Spearman tingkat dukungan instrumental dengan tingkat self esteem $(n=32)$

\begin{tabular}{lcc}
\hline & Koefisien Korelasi & Sig. (2- tailed) \\
\hline $\begin{array}{l}\text { Dukungan } \\
\text { Instrumental }\end{array}$ & $.636^{* *}$ & 0.000 \\
\cline { 1 - 1 } Self-Esteem & & \\
\hline
\end{tabular}

Dari tabel diatas, diketahui nilai Sig. (2-tailed) adalah 0.000 atau $\mathrm{p}<0.05$ serta nilai koefisien korelasinya 0,636. Maka kesimpulannya secara terdapat hubungan yang signifikan dan kuat antara variabel dukungan instrumental dengan variabel tingkat selfesteem pada pasien stroke tahap rehabilitasi di Rumah Sakit dr. Gondo Suwarno Ungaran. 
Tabel 7. Hasil Uji Rank Spearman tingkat dukungan informasional dengan tingkat self esteem $(n=32)$

\begin{tabular}{|c|c|c|}
\hline & Koefisien Korelasi & Sig. (2- tailed) \\
\hline $\begin{array}{l}\text { Dukungan } \\
\text { Informasional } \\
\text { Self-Esteem }\end{array}$ & $.539^{* *}$ & 0.001 \\
\hline
\end{tabular}

Dari tabel diatas, diketahui nilai Sig. (2-tailed) adalah 0.001 atau $\mathrm{p}<0.05$ serta nilai koefisien korelasinya 0,539. Maka kesimpulannya secara terdapat hubungan yang signifikan dan kuat antara variabel dukungan informasional dengan variabel tingkat self-esteem pada pasien stroke tahap rehabilitasi di Rumah Sakit dr. Gondo Suwarno Ungaran.

\section{PEMBAHASAN}

Pasien stroke tahap rehabilitasi di RS dr. Gondo Suwarno Ungaran cenderung lebih didominasi oleh responden dengan status dukungan keluarga yang baik dan cukup baik dengan masing masing berujumlah 13 orang $(40,6 \%)$ dengan rata rata skor yang didapatkan adalah 28,09. Hasil tersebut didukung oleh penelitian Zai (2020) yang dimana sebagian besar dari para keluarga cenderung akan lebih memberikan perhatian yang lebih ketika pasien ada dalam kondisi sakit, khususnya saat menjalani rehabilitasi dalam pemulihan penyakit stroke.

Pada variabel terdapat domain yang diantaranya adalah dukungan emosional, penghargaan, instrumental, dan informasional. Dan pada penelitian ini yang memiliki nilai terendah atau jarang diberikan oleh keluarga adalah dukungan informasional. Responden yang mendapatkan nilai dukungan informasional rendah adalah 14 orang (43.8\%) dengan skor rata rata 7,09. Hal tersebut telah didukung dengan penelitian dari Zai (2020) yang mendapatkan hasil bahwa keluarga lebih sedikit untuk memberikan dukungan secara informasional dibandingkan dengan dukungan lainnya. Dukungan informasional ini berbentuk penyediaan informasi dengan contoh meminta kejelasan pada petugas kesehatan terkait terapi untuk penderita stroke(Zai et al., 2019).

Peran serta akan dukungan keluarga amat memberikan pengaruh yang signifikan pada proses rehabilitasi yang dijalan oleh pada penderita stroke. Hasil penelitian sebelumnya telah menggambarkan peranan keluarga dalam proses rehabilitasi penderita stroke dirasa penting, sejumlah $80 \%$ hingga $90 \%$ perawatan di bidang kesehatan dilakukan dari pihak keluarga keluarga sendiri dibandingkan prog - program kesehatan di instansi. Terjadinya hal tersebut adalah dikarenakan di kehidupan sehari harinya, seorang penderita stroke lebih menggantungkan dirinya kepada orang - orang terdekatnya seperti halnya keluarga (Tyas, 2019).

Tingkat self esteem para responden penderita stroke tahap rehabilitasi di RS dr. Gondo Suwarno Ungaran didominasi oleh responden dengan tingkat self esteem tinggi, yaitu sebanyak 16 orang $(50 \%$ ) dengan nilai rata - rata (mean) 27,28 . Hal tersebut sesuai dengan penelitian Shida (2014) yang menunjukkan bahwa pada pasien stroke hanya terjadi sedikit penurunan harga diri dengan rata rata tingkat self esteem melalui 
kuesioner RSES 32,12 dari keseluruhan skor 40 yang berarti rata rata responden memiliki tingkat self esteem yang tinggi.

Penderita stroke cenderung akan memiliki kepercayaan yang tinggi apabila mampu memenuhi kebutuhan sehari - harinya. Dalam memenuhi kebutuhannya sehari - hari, orang terdekat seperti keluarga memiliki peran besar karena keluarga adalah orang yang paling sering berkomunikasi dan berinteraksi dengan pasien stroke. Mampunya seorang pasien stroke memenuhi kebutuhannya seperti mandi, toileting, dan menjaga kerapian diri otomatis akan meningkatkan kepercayaan dirinya dan pasien akan lebih menghargai dirinya sebagai manusia yang ingin segera sehat kembali (Shida et al., 2014).

Terdapat hubungan yang signifikan yang kuat antara dukungan keluarga dengan tingkat self esteem dengan nilai Sig. (2-tailed) adalah 0.000 atau $\mathrm{p}<0.05$ serta nilai koefisien korelasinya 0,658. Hasil ini juga searah dengan penelitian serupa sebelumnya dari Okthavia (2015) dengan nilai signifikansi sig(2-tailed) $=0,02$ dan koefisien korelasi bernilai 0,552 yang berarti memiliki keeratan yang kuat. Semakin tinggi dukungan yang diberikan keluarga pada penderita stroke dengan mencakup dukungan informasional, dukungan instrumental, dukungan emosional, dukungan penghargaan akan mempengaruhi penderita stroke dalam aspek menghargai dirinya atas kondisinya saat ini (Okthavia, 2015).

Terdapat hubungan yang signifikan yang kuat antara dukungan emosional dan penghargaan dengan tingkat self esteem dengan nilai Sig. (2-tailed) adalah 0.000 atau $\mathrm{p}<0.05$ serta nilai koefisien korelasinya 0,628. Hasil penelitian ini sejalan dengan penelitian serupa dari Sucita Lestari dalam Tyas (2019) dengan nilai $\mathrm{p}<0,05$. Dalam melaksanakan program rehabilitasi, rasa penghargaan serta support emosional sangat pasien stroke perlukan karena akan menumbuhkan sifat patuh dari para pasien yang menjalani program rehabilitasi(Tyas, 2019). dukungan penghargaan berperan menjadi umpan balik atas hal hal uang dilakukan oleh individu. Dukungan penghargaan umumnya keluarga berikan dengan cara memberikan pujian untuk pasien stroke apabila terdapat kemajuan dalam hal pengobatan maupun pemulihan. Selanjutnya dukungan emosional juga dapat keluarga berikan dengan cara memberi semangat dan pendapat dalam hal pemecahan masalah yang ada pada pasien stroke (Setyoadi et al., 2017). Maka dengan adanya dukungan baik secara emosional dan penghargaan mampu memacu kepercayaan diri pasien stroke sehingga proses pemulihan berjalan secara optimal

Terdapat hubungan yang signifikan yang kuat antara dukungan instrumental dengan tingkat self esteem dengan nilai Sig. (2-tailed) adalah 0.000 atau $\mathrm{p}<0.05$ serta nilai koefisien korelasinya 0,636. Hasil tersebut sejalan dengan penelitian dari Zai (2020) yang mendapatkan hasil dari seluruh responden yang mendapat dukungan instrumental baik dengan tingkat self esteem yang tinggi yaitu sebanyak $75 \%$ responden. Dukungan instrumental diberikan dalam bentuk penyediaan fasilitas dan materi yang mampu membantu secara langsung yang contohnya adalah penyediaan alat bantu, penyediaan kecukupan nutrisi serta penyediaan dana (Simbolon, 2017) .Pemberian dukungan instrumental misalnya dengan menyediakan berbagai kebutuhan saat proses rehabilitasi pasien dapat menjadi faktor pencetus self esteem meningkat sehingga proses pemulihan mampu terlaksana lebih efektif (Zai et al., 2019). 
Terdapat hubungan yang signifikan yang kuat antara dukungan informasional dengan tingkat self esteem dengan nilai Sig. (2-tailed) adalah 0.001 atau $\mathrm{p}<0.05$ serta nilai koefisien korelasinya 0,539. Hal tersebut sejalan dengan penelitian dari Zai (2020) yang mendapatkan hasil dari seluruh responden yang mendapat dukungan informasional baik dengan tingkat self esteem yang tinggi yaitu sebanyak $71 \%$ responden. Dukungan informasional dapat berupa penyediaan informasi saat keluarga meminta penjelasan pada tenaga medis berkaitan dengan terapi yang diharuskan untuk pasien stroke jalani, menjelaskan manfaat dari dilakukannya pemulihan/rehabilitasi dan juga mencarikan informasi berkaitan dengan jenis rehabilitasi yang cocok untuk pasien jalani (Fuady et al., 2016). Pemberian dukungan berupa saran dan informasi adalah bentuk dukungan yang secara efektif akan berpengaruh pada tingkat kepercayaan diri dan juga tingkat self esteem pada pasien stroke dikarenakan pasien semakin tahu dan wawasannya bertambah sehingga rasa kecemasan akan rehabilitasi berkurang dan proses rehabilitasi dapat berjalan secara optimal (Zai et al., 2019).

\section{SIMPULAN}

Berdasarkan uraian dan pembahasan yang peneliti susun, maka dapat peneliti simpulkan dari penelitian ini terdapat hubungan antara dukungan keluarga baik secara holistik maupun aspek-aspek di dalamnya yaitu dukungan emosional, penghargaan, instrumental, dan informasional dengan tingkat self-esteem pada pasien stroke tahap rehabilitasi. Bagi peneliti selanjutnya,dapat dijadikan sumber informasi dan referensi untuk penelitian yang lebih baru agar peneliti baru dapat lebih mengendalikan confounding factor yang kemungkinan dapat muncul serta berpengaruh pada penelitian yang dijalankan. Peneliti selanjutnya juga diharapkan menambahkan variabel lainnya yang berkemungkinan dapat berkorelasi dengan variabel penelitian saat ini.

\section{REFERENSI}

Artaya, I. P. (2019). Uji Rank Spearman. Research Gate, January, 3-5. https://doi.org/10.13140/RG.2.2.16006.01606

An, E., Suh, S., \& Kim, E. (2019). Influences of Self-esteem, Rehabilitation Motivation on Quality of Life in Stroke Pateints with Rehabilitation Therapy. 20(3), 176-187.

Chung, M. L., Bakas, T., Plue, L. D., \& Williams, L. S. (2016). Effects of self-esteem, optimism, and perceived control on depressive symptoms in stroke survivor-spouse dyads. Journal of Cardiovascular Nursing. https://doi.org/10.1097/JCN.0000000000000232

Fuady, N., Sjattar, E. L., \& Hadju, V. (2016). Pengaruh pelaksanaan discharge planning terhadap dukunggan psikososial keluarga merawat pasien stroke DI RSUP DR. Wahidin Sudirohusodo. J Jst Kesehatan, 6(2).

Hinkle, J., \& Cheever, K. (2017). Brunner \& Suddarth's Textbook of Medical-Surgical Nursing. Lippincot William \& Wilkins.

Husnaniyah, D. (2017). Faktor-Faktor Yang Berpengaruh Terhadap Harga Diri (Self Esteem) Penderita Tuberkulosis Paru Di Wilayah Eks Kawedanan Indramayu. The 
Indonesian Journal Of Health Sciencecience, 9(1), 1-12. https://doi.org/10.15797/concom.2019..23.009

Kosasih, C. E., Punthmatharith, B., \& Boonyasopun, U. (2020). Family support for patients with stroke : a systematic review. 10(3), 47-56.

Maulani, Sari, A. L., \& Lestari, S. T. (2017). Hubungan Motivasi dan Dukungan Keluarga dengan Upaya Rehabilitasi pada Pasien Pasca Stroke di Poli Saraf Rumah Sakit Umum Daerah H.Abdul Manap Kota Jambi Tahun 2017. Jurnal Stikes Harapan Ibu, 120-128.

Okthavia, S. (2015). Hubungan Antara Dukungan Sosial Keluarga Terhadap Tingkat Self Esteem Pada Penderita Pasca Stroke ( The Correlations Between Family Social Support With Self Esteem Level In Patient Who Have Post- Stroke ). 3(2), $110-118$.

Potter, P. A., \& Perry, A. G. (2016). Fundamentals of Nursing (9th ed.). Elsevier Health Sciences.

Setyoadi, S., Nasution, T. H., \& Kardinasari, A. (2017). Hubungan Dukungan Keluarga Dengan Kemandirian Pasien Stroke Di Instalasi Rehabilitasi Medik Rumah Sakit Dr. Iskak Tulungagung. Majalahkesehatan, 4(3). https://doi.org/10.21776/ub.majalahkesehatan.2017.004.03.5

Shida, J., Sugawara, K., Goto, J., \& Sekito, Y. (2014). Relationship between self-esteem and living conditions among stroke survivors at home. 229-240. https://doi.org/10.1111/jjns.12024

Simbolon, P. S. (2017). Hubungan Dukungan Keluarga Dengan Konsep Diri Pasien Stroke Di Rumah Sakit Santa Elisabeth Medan. Jurnal Ilmu Dan Teknologi Kesehatan, 4(2). https://doi.org/10.32668/jitek.v4i2.66

Tyas, K. F. C. (2019). Hubungan Antara Rehabilitasi Dan Dukungan Keluarga Dengan Kejadian Stroke Berulang (Studi Kasus Di Rsud Dr. Adhyatma, Tugurejo Semarang). Jurnal Kesehatan Masyarakat (e-Journal), 7(4), 728-734.

Zai, Y., Bu'ulolo, K., Fajariani, N., Hulu, Y., Gulo, R. E., \& Nurhayati, E. L. (2019). Hubungan Dukungan Keluarga Dengan Tingkat Self Esteem (Harga Diri) Pada Penderita Stroke Di Rumah Sakit Umum Royal Prima Medan 2019. Jurnal Riset Hesti Medan Akper Kesdam I/BB Medan. https://doi.org/10.34008/jurhesti.v4i2.110 